\title{
VARIABILITY OF CATION-EXCHANGE CAPACITY (CEC) OF FEN PEATS IN VERTICAL PROFILES FROM EASTERN AND CENTRAL POLAND IN RELATION TO FUNCTION OF PEATLANDS AS NATURAL GEOLOGICAL BARRIERS
}

\author{
Pawel Rydelek, Anna Bąkowska, Piotr Zawrzykraj \\ Faculty of Geology, University of Warsaw, Żwirki i Wigury 93, 02-089 Warsaw, Poland, \\ e-mail:Pawel.Rydelek@uw.edu.pl
}

\begin{abstract}
An analysis of cation-exchange capacity (CEC) variability of peats is presented in vertical profiles from eastern and central Poland. $\mathrm{CEC}$ values were compared with ash content (Ac), $\mathrm{pH}$ and $\mathrm{CaCO}_{3}$ content. Eight peatlands were selected for research in the following areas: Warsaw Plateau (2 objects), Siedlce Plateau (2 objects), Lubartów Plateau (2 objects), Nałęczów Tableland (1 object) and Dobrohusk Depression (1 object). The peatlands represented a fen peat type of similar botanic compositions of sediments, but they differed in the area, peat thickness and drainage conditions. Characteristic regularities in CEC variability were noted in the peatlands and there were three types of CEC variability in vertical profiles. Carbonate peats (types 1 and 2) had the highest $\mathrm{pH}$ and definitely the highest values of CEC. In vertical profiles, there was also a zonation, but the regularities similar to non-carbonate peats were not observed. Different distribution of physical and chemical parameters were established in vertical profiles in partly drained peatlands (with a muck layer on top) with non-carbonate peats (type 3) and there were three distinct zones in vertical profiles, with different Ac and CEC. Determination of the vertical CEC variability and other physical and chemical parameters in peatlands made it possible to distinguish zones with potentially most beneficial isolation conditions.
\end{abstract}

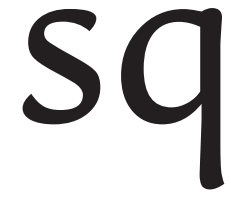

Key words: natural geological barrier, peat, fen, cation-exchange capacity

Manuscript received 28 April 2016, accepted 26 October 2016

\section{INTRODUCTION}

The term 'natural geological barrier' (soil layer that isolates a shallow groundwater from pollution) is used both in case of soil used as insulation of sealing landfills (Langer, 1998; Zhou and Li, 2001; Dorn and Tantiwanit, 2001; Łuczak-Wilamowska, 2013) and in a regional scale in case of natural in situ soil layers (Syrovetnik et al., 2007; Falkowska, 2009; Rydelek, 2011). Apart from low permeability the geological barriers should indikcate a high natural retention capacity for hazardous substances, large thickness and high homogeneity (Dorn and Tantiwanit, 2001; Majer, 2007). These criteria are commonly fulfilled by organic soils within peatlands. Peats have high absorption capabilities (cf. Ho and McKay, 1999; Allen et al., 2004; Ma and Tobin, 2004; Twardowska and Kyzioł, 1996; Twardowska et al., 1999; Kyzioł, 2002; Borkowski et al., 2013) and they are usually connected with high content of organic matter (indicating a low ash content). Depending on a composition of organic matter (humid acid content), a cation-exchange capacity of organic matters is 4 to 12 times higher than of clay minerals
(Appelo and Postma, 1993). Peats are classified as soils with extraordinarily high variability of physical and chemical parameters: ash content $(\mathrm{Ac})$, moisture content, density and porosity (Ingram, 1978; Hobbs, 1986). A hydraulic conductivity oscillates in a wide range between $10^{-10}$ and $10^{-3} \mathrm{~m} / \mathrm{s}$ in fen peats (Boelter, 1965; Hobbs, 1986; Hoag and Price, 1995; Rizutti et al., 2004; Beckwith et al., 2003a, 2003b; Rydelek et al., 2015). Variability of peat properties is an outcome of processes that run during deposition (process of sedentation) and post-depositional stages. Variability of different parameters is observed both in vertical profiles of peatlands (Rydelek 2005; Domińczak and Okupny 2010; Borówka et al., 2015; Ścibior et al., 2015; Kittel et al., 2016; Pawłowski et al., 2016) and in horizontal plane (Pawłowski et al., 2014). Aim of this paper was to establish regularities in CEC variability of peats in vertical profiles of fens in eastern and central Poland (Fig. 1) against other varied physical and chemical parameters. Studied peatlands were similar in botanic composition of peats, but they were different in chemical and physical properties, thickness, area and drainage conditions. 


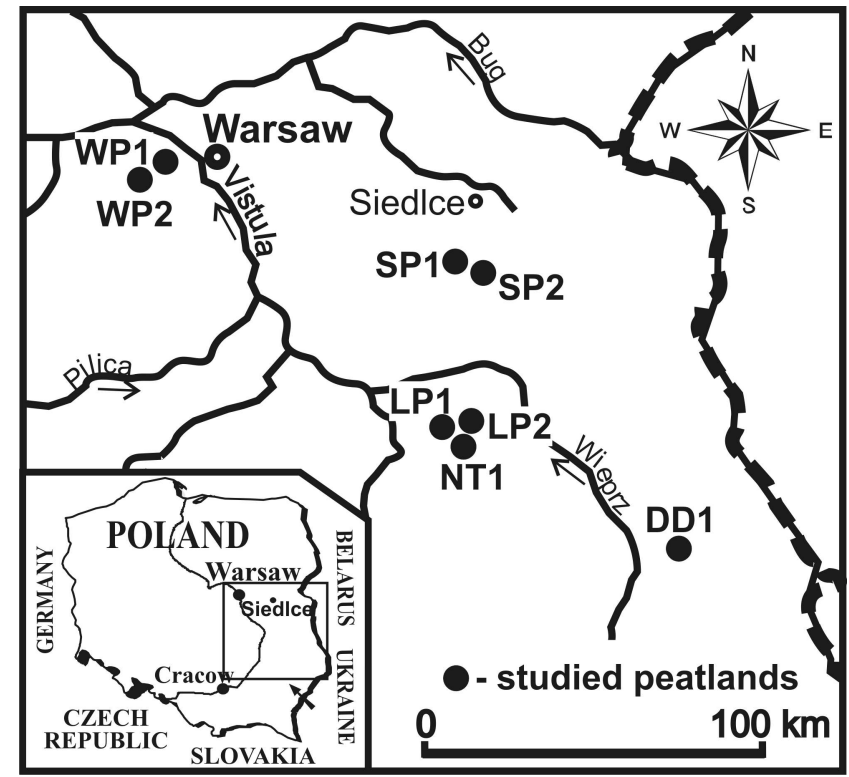

Fig. 1. Location of the studied peatlands. WP - Warsaw Plateau, SP - Siedlce Plateau, LP - Lubartów Plateau, NT - Nałęczów Tableland, DD - Dorohusk Depression.

\section{MATERIALS AND METHODS}

Eight peatlands were selected in the following areas: Warsaw Plateau (2 objects marked as WP1 and WP2), Siedlce Plateau (2 objects marked as SP1 and SP2), Lubartów Plateau (2 objects marked as LP1 and LP2), Nałęczów Tableland (1 object marked as NT1) and Dobrohusk Depression (1 object marked as DD1). Except for DD1 peatland at Pawłów, $20 \mathrm{~km}$ west of Chełm, all other peatlands represented the val- ley-bog type. Peatlands WP1 and WP2 were located in the valleys of Raszynka and Utrata rivers, SP1 and SP2 in the valley of the Bystrzyca River, LP1 and LP2 in the valley of the Kurówka River, while NT1 in the valley of the StrugaKurów River (tributary of the Kurówka River).

In total, 16 vertical profiles were examined for the CEC variability. Two most representative profiles from every peatland were selected and marked with symbols "a" and "b" (e.g. LP1a and LP1b), so the widest spectrum of different types and features of peats could be considered.

Peat samples for e thlaboratory studies were collected at every noticed macroscopic change of botanic composition or degree of decomposition but not less often than every $30 \mathrm{~cm}$. Peat type and degree of decomposition were determined for every sample using shortened three-step approach by Okruszko (1974): R1 - fibrous peats (poorly decomposed), R2 pseudo-fibrous peats (moderately decomposed) and R3 amorphous peats (highly decomposed).

Basic properties of peats (ash content $\mathrm{A}_{\mathrm{C}}, \mathrm{pH}, \mathrm{CaCO}_{3}$ content and CEC) were determined for all samples. Ash content was determined after ignition at $550 \mathrm{C}$ (Andrejko et al., 1983). The division of peats as to the ash content according to Okruszko (1994) was adopted: non-silty peats (ash content below $25 \%$ ), slightly silty (25-50\% of ash content) and strongly silty (50-80\% of ash content). Degree of decomposition was specified for non-silted peats only (Borys, 1993). Acidity $(\mathrm{pH})$ of peat was determined in suspension in a distilled water by using electometric method, while $\mathrm{CaCO}_{3}$ content was determined by Scheibler's method (cf. Myślińska, 2010). Depending on $\mathrm{CaCO}_{3}$ content, a classification of Okruszko (1976) was adopted: non-carbonate peats $\left(\mathrm{CaCO}_{3}<5 \%\right)$, poorly carbonate $(5-20 \%)$, moderately carbonate $(20-45 \%)$ and highly carbonate $\left(\mathrm{CaCO}_{3}>45 \%\right)$. Cation-exchange ca-

Table 1

Basic characteristics of studied peatlands and average values of physical and chemical parameters of peats (there are coefficient of variation given in parentheses)

\begin{tabular}{|c|c|c|c|c|c|c|c|c|}
\hline & \multicolumn{8}{|c|}{ Peatland } \\
\hline & WP1 & WP2 & SP1 & SP2 & LP1 & LP2 & NT1 & DD1 \\
\hline Area [ha] & 65 & 51 & 275 & 91 & 180 & 25 & 43 & 38 \\
\hline $\begin{array}{l}\text { Maximum thick- } \\
\text { ness [m] }\end{array}$ & 1.5 & 1.4 & 4.0 & 3.0 & 3.5 & 3.7 & 3.3 & 1.7 \\
\hline Peat type & $\begin{array}{l}\text { reed peat } / \text { tall } \\
\text { sedge peat }\end{array}$ & $\begin{array}{c}\text { alder peat/ reed } \\
\text { peat }\end{array}$ & $\begin{array}{c}\text { tall sedge } \\
\text { peat/reed peat }\end{array}$ & $\begin{array}{c}\text { tall sedge } \\
\text { peat/alder peat }\end{array}$ & $\begin{array}{c}\text { alder peat } / \text { reed } \\
\text { peat/tall sedge } \\
\text { peat }\end{array}$ & $\begin{array}{c}\text { reed peat/alder } \\
\text { peat }\end{array}$ & $\begin{array}{c}\text { tall sedge } \\
\text { peat/alder peat }\end{array}$ & $\begin{array}{l}\text { reed peat } / \text { tall } \\
\text { sedge peat }\end{array}$ \\
\hline $\begin{array}{l}\text { Maximum thick- } \\
\text { ness of muck [m] }\end{array}$ & 0.3 & 0.4 & 0.3 & 0.4 & 0.5 & 0.4 & 0.4 & 0.2 \\
\hline $\begin{array}{l}\text { Degree of decom- } \\
\text { position }\end{array}$ & silted & silted & $\mathrm{R} 2 / \mathrm{R} 1$ & $\mathrm{R} 2 / \mathrm{R} 1$ & $\mathrm{R} 2 / \mathrm{R} 3$ & $\mathrm{R} 2 / \mathrm{R} 1$ & silted & $\mathrm{R} 2$ \\
\hline $\begin{array}{c}\mathrm{Ac} \\
\%\end{array}$ & $\begin{array}{c}42.4 \\
(0.22)\end{array}$ & $\begin{array}{c}51.6 \\
(0.31)\end{array}$ & $\begin{array}{c}20.7 \\
(0.47)\end{array}$ & $\begin{array}{c}37.1 \\
(0.57)\end{array}$ & $\begin{array}{c}32.4 \\
(0.46)\end{array}$ & $\begin{array}{c}47.9 \\
(0.41)\end{array}$ & $\begin{array}{c}55.1 \\
(0.18)\end{array}$ & $\begin{array}{c}26.2 \\
(0.19)\end{array}$ \\
\hline $\begin{array}{c}\mathrm{CaCO}_{3} \\
\% \\
\end{array}$ & $\begin{array}{c}13.9 \\
(0.84)\end{array}$ & $\begin{array}{c}1.3 \\
(0.37) \\
\end{array}$ & $\begin{array}{c}2.2 \\
(0.47)\end{array}$ & $\begin{array}{c}13.7 \\
(1.16)\end{array}$ & $\begin{array}{c}2.1 \\
(0.49) \\
\end{array}$ & $\begin{array}{c}16.7 \\
(1.06)\end{array}$ & $\begin{array}{c}36.8 \\
(0.36) \\
\end{array}$ & $\begin{array}{c}4.4 \\
(1.26)\end{array}$ \\
\hline $\begin{array}{c}\mathrm{pH} \\
\mathrm{H}_{2} \mathrm{O} \\
\end{array}$ & $\begin{array}{c}6.7 \\
(0.06) \\
\end{array}$ & $\begin{array}{c}5.6 \\
(0.05) \\
\end{array}$ & $\begin{array}{c}6.0 \\
(0.06) \\
\end{array}$ & $\begin{array}{c}7.0 \\
(0.03) \\
\end{array}$ & $\begin{array}{c}5.7 \\
(0.06) \\
\end{array}$ & $\begin{array}{c}6.4 \\
(0.06) \\
\end{array}$ & $\begin{array}{c}7.2 \\
(0.03) \\
\end{array}$ & $\begin{array}{c}6.4 \\
(0.05) \\
\end{array}$ \\
\hline $\begin{array}{c}\mathrm{CEC} \\
\mathrm{cmol} / \mathrm{kg}\end{array}$ & $\begin{array}{c}123 \\
(0.12)\end{array}$ & $\begin{array}{c}96 \\
(0.14)\end{array}$ & $\begin{array}{c}117 \\
(0.08)\end{array}$ & $\begin{array}{c}132 \\
(0.11)\end{array}$ & $\begin{array}{c}107 \\
(0.14)\end{array}$ & $\begin{array}{c}120 \\
(0.14)\end{array}$ & $\begin{array}{c}143 \\
(0.04)\end{array}$ & $\begin{array}{c}120 \\
(0.12)\end{array}$ \\
\hline
\end{tabular}

$\mathrm{Ac}$ - ash content, $\mathrm{CaCO} 3$ - calcium carbonate content, $\mathrm{CEC}$ - cation-exchange capacity. WP - Warsaw Plateau, SP - Siedlce Plateau, LP - Lubartów Plateau, NT - Nałęczów Tableland, DD - Dorohusk Depression. 

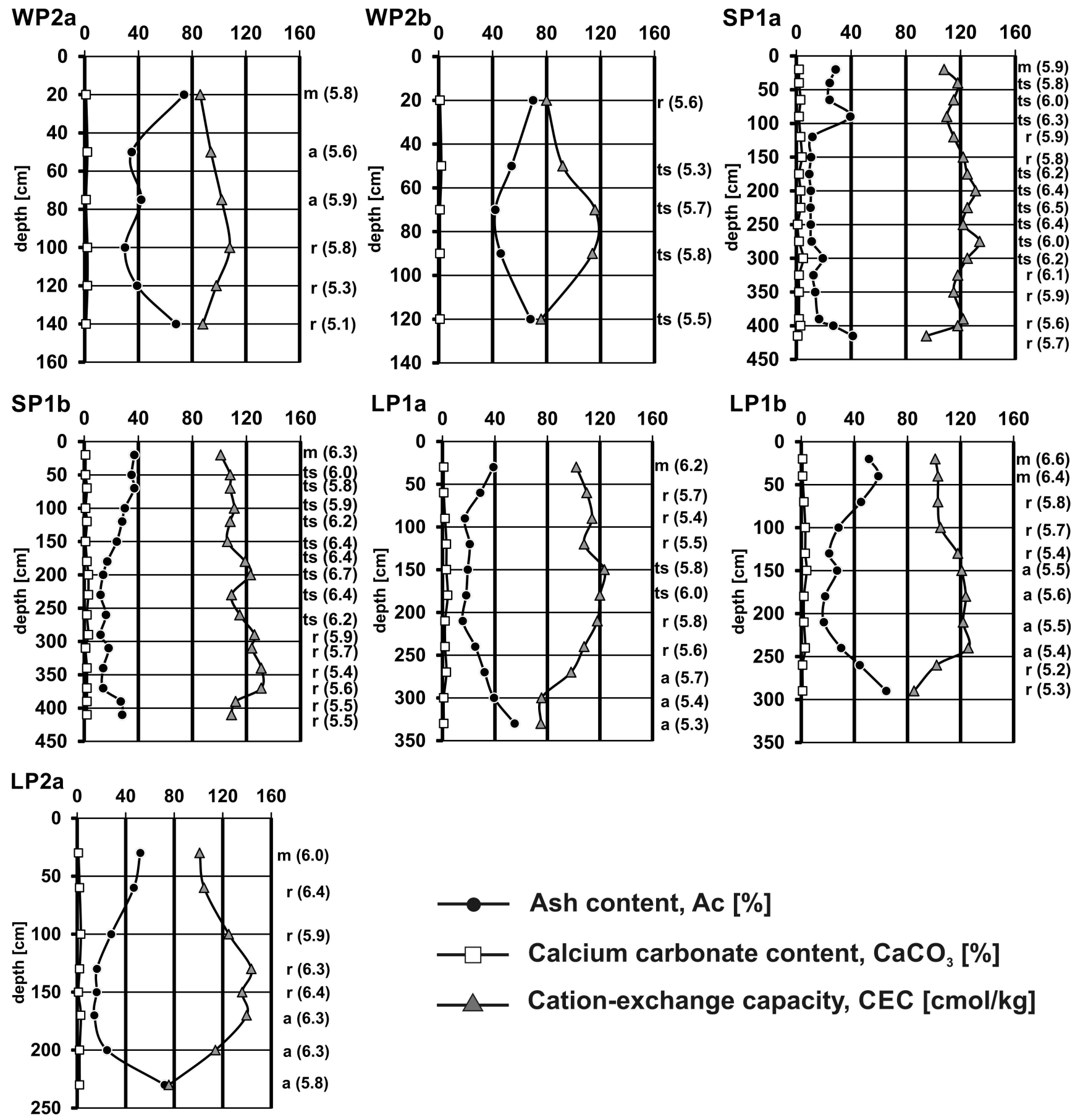

\section{$\longrightarrow$ Ash content, Ac [\%] \\ $-\square-$ Calcium carbonate content, $\mathrm{CaCO}_{3}[\%]$ \\ $\longrightarrow$ Cation-exchange capacity, CEC [cmol/kg]}

Fig. 2A. Variability of cation-exchange capacity (CEC) and ash content (Ac) in vertical profiles of non-carbonate peatlands, $\mathrm{pH}$ given in parentheses; $\mathrm{m}$ - muck, ts - tall sedge peat, $\mathrm{r}$ - reed peat, a - alder peat.

pacity was determined by the copper sorption method (Sapek, 1982). This method belongs to batch experiments and is based on measurement of copper ions concentration in a solution before and after a reaction with the soil.

\section{RESULTS}

Basic data of studied peatlands (16 profiles), CEC value and other physical and chemical parameters were presented (Table 1). The highest CEC values $(>130 \mathrm{cmol} / \mathrm{kg})$ were noted in peats at SP2 and NT1. Peats in those peatlands indi- cated a high content of $\mathrm{CaCO}_{3}$ and slightly alkaline $\mathrm{pH}$. The lowest values of CEC were observed in peats at WP2 and LP1 (96 and $107 \mathrm{cmol} / \mathrm{kg}$ ). In those peatlands there were non-carbonate peats of $\mathrm{pH}<6$. CEC values in the remaining peatlands were similar and varied (117 and $123 \mathrm{cmol} / \mathrm{kg})$.

Two types of profiles were compared considering the CEC variability: profiles with non-carbonate peats only (Fig. 2A) and profiles with highly carbonate peats (Fig. 2B). 


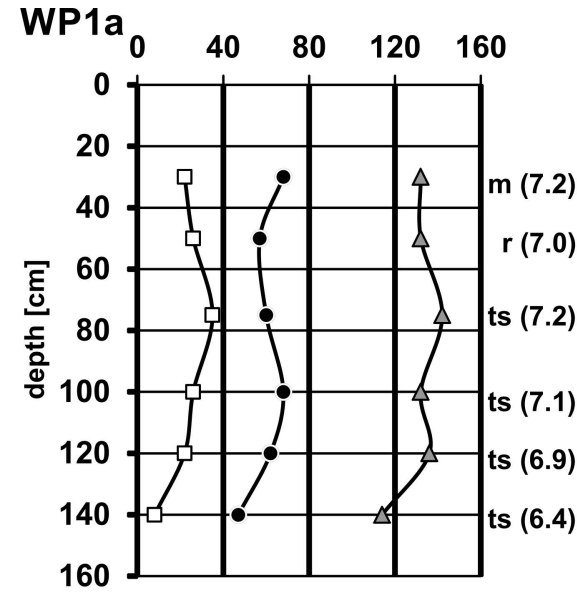

NT1b $_{0} \quad 40 \quad 80 \quad 120 \quad 160$
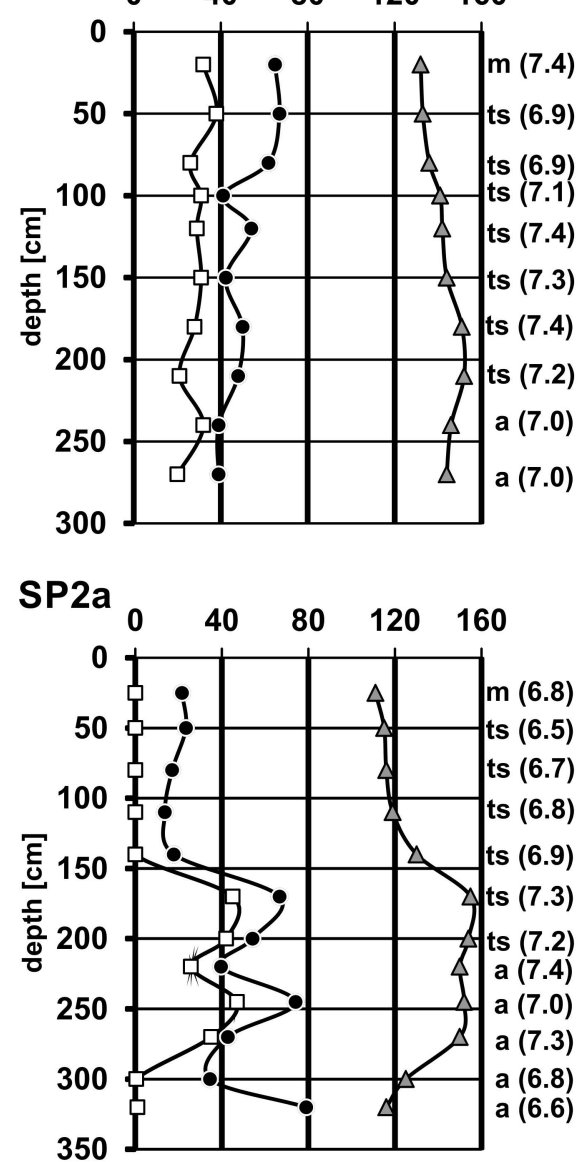
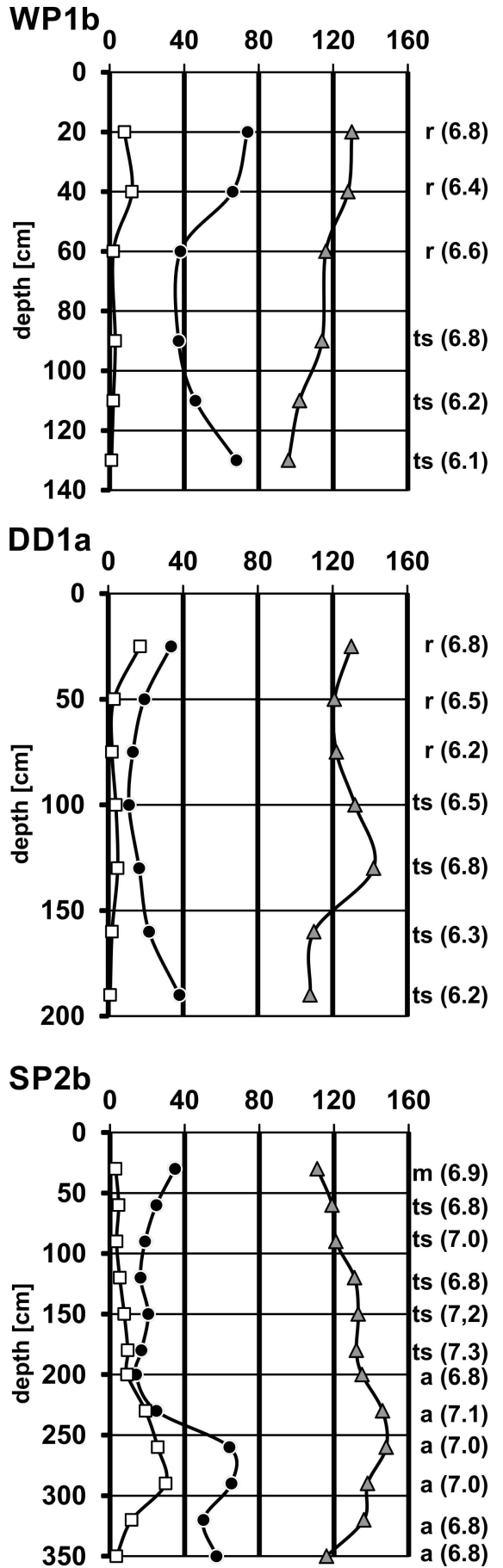

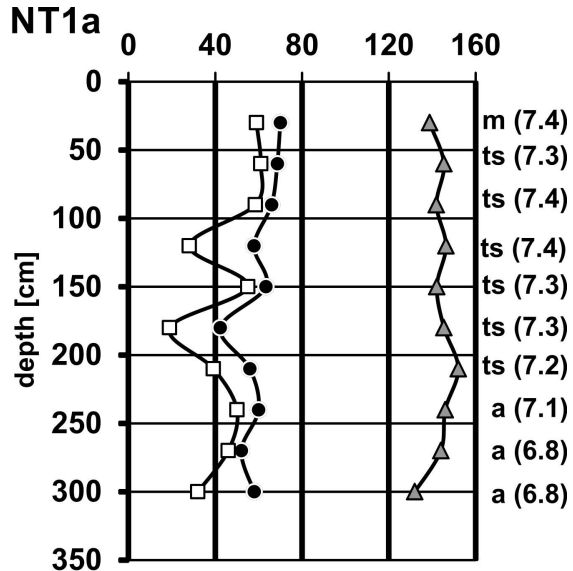

DD1b $_{0} \quad 40 \quad 80 \quad 120 \quad 160$
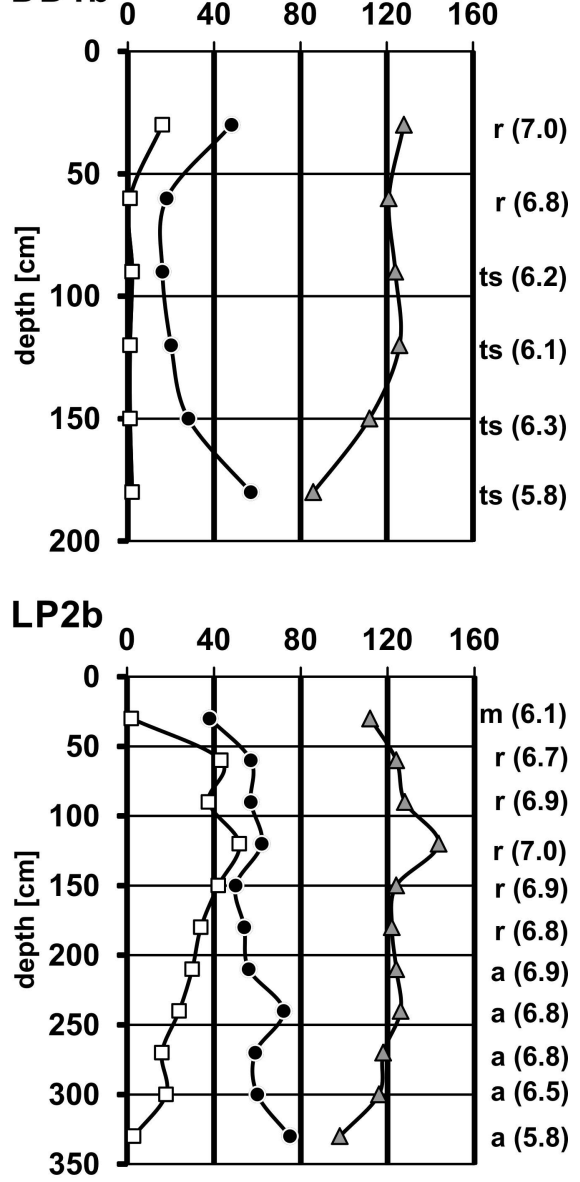

Fig. 2B. Variability of cation-exchange capacity (CEC) and ash content (Ac) in vertical profiles of carbonate peatlands, $\mathrm{pH}$ given in parentheses; $\mathrm{m}$ - muck, ts - tall sedge peat, $\mathrm{r}$ - reed peat, $\mathrm{a}$ - alder peat.

\section{DISCUSSION}

The analysis of CEC values variability in 16 vertical profiles (Fig. 2A, B) enabled to distinguished three types of vertical profiles.

The type 1 including WP1a, NT1a and NT1b profiles indicated high CEC values with low variability in the whole peat thickness (except for a single sample, all CEC values were $<130 \mathrm{cmol} / \mathrm{kg}$ ). In vertical profiles there were mainly carbonate peats (moderate and highly carbonate) with high $\mathrm{pH}$ and high ash content (41 to $70 \%$ ) linked mainly to $\mathrm{CaCO}_{3}$ content. Calcium carbonate occurred in the peats as of idiomorphic microcrystals, that indicated crystallization within a peat and autogenesis (Rydelek, 2013). High CEC values in profiles of the type 1 were established independent from peat type and independent from drainage conditions. In the muck layer that occurred in profiles of the studied peatlands, the high CEC levels were observed $(134 \mathrm{cmol} / \mathrm{kg})$. In peats that were a part of the type 1 profiles there was no meaningful relation between CEC and ash content (Fig. 3).

The type 2, which includes profiles DD1a, DD1b, LP2b, WP1b, SP2a and SP2b, had also the samples with high CEC 

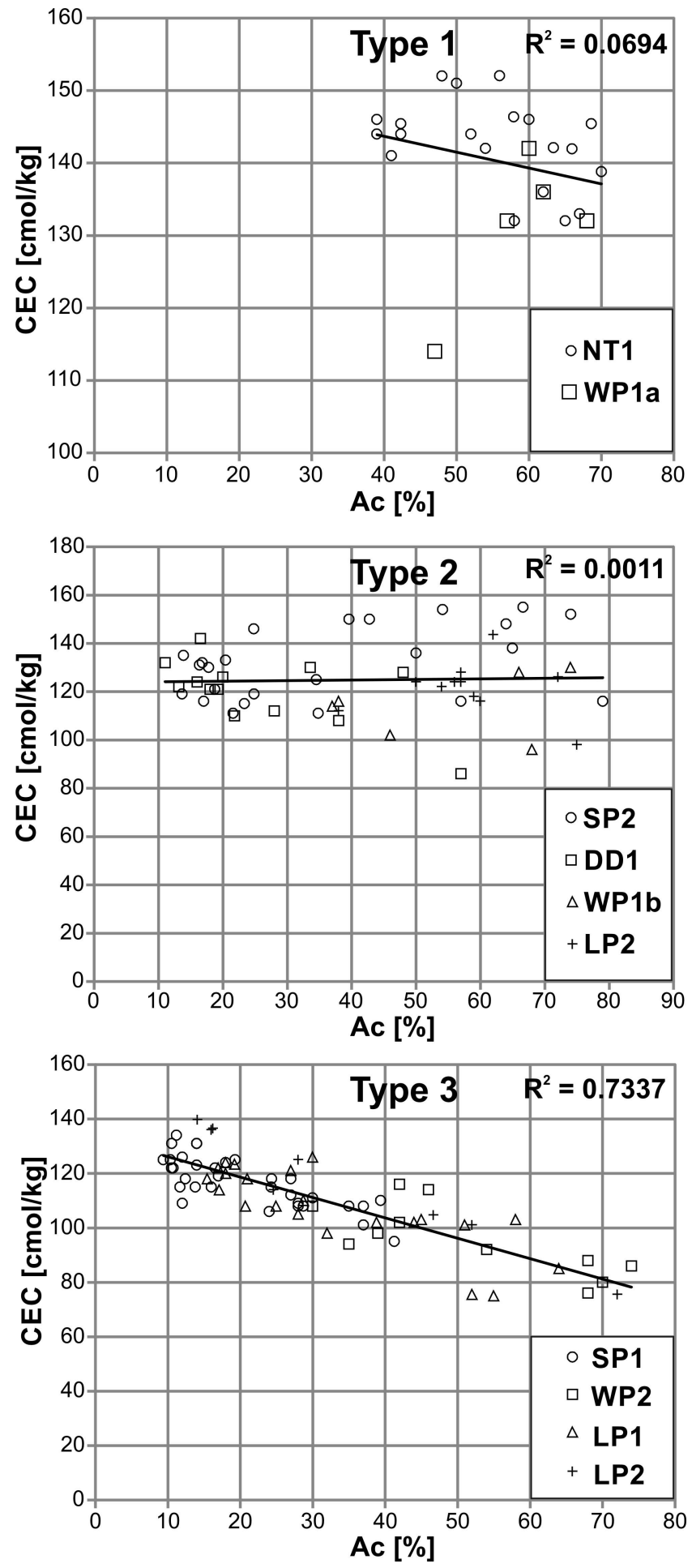

Fig. 3. Relationship between cation-exchange capacity (CEC) and ash content (Ac) in the studied peatlands.

$(>100 \mathrm{cmol} / \mathrm{kg}$ ) but with highly varied. In single profiles, there were peats with high variability of $\mathrm{pH}$, ash content and $\mathrm{CaCO}_{3}$ content. The highest values of $\mathrm{CEC}$ in the type 2 profiles were observed in samples with the highest $\mathrm{CaCO}_{3}$ content and the highest $\mathrm{pH}$. At the same time in thr profiles of partly drained peatlands in a muck layer in a top of a peatland (profiles LP2b, SP2a and SP2b), the lower values of CEC were noted if compared with the lower layers of a peat. Just as with a peat of the type 1, a dependency between CEC and Ac was described by the very low value of $R^{2}=0,0011$.

The type 3 comprised a peat with the lowest CEC (rarely $>120 \mathrm{cmol} / \mathrm{kg}$ ). This type occurred in the remaining profiles (SP1a, SP1b, LP1a, LP1b, LP2a, WP2a, WP2b), predominated by non-carbonate and poorly-carbonate peats with the lowest $\mathrm{pH}$ and with a top layer of muck. of CEC values in the profiles of the type 3 indicated clear connection with the ash content $\left(\mathrm{R}^{2}=0.7337\right)$ (Fig. 3$)$.

The highest values of CEC, as well as the lowest ash content occurred in the middle part of the profiles, regardless the type of peat. High ash content and subsequently lower CEC value in the top part of the profiles was connected with muck occurrence.

Lower values of organic matter and subsequently lower CEC values in the bottom parts represented the first deposition phase. A sedentation started directly on a mineral subsoil, thus in a bottom part the peat was enriched in mineral constituents.

CEC values of the studied peat did not differ significantly from other peats in the Polish Lowland (e.g. Falkowska, 2002; Kyzioł, 2002) and were much higher than in mineral soils (Falkowska, 2009).

\section{CONCLUSIONS}

Apart from different in characteristics of peats in the studied peatlands, there were also varied parameters (including CEC) within single peatlands. It allowed distinguishing the zones of similar physical and chemical properties within the studied peatlands.

Among the described three types, the lowest CEC values were observed in the type 3 , in which non-carbonate peat with low ash content and low $\mathrm{pH}$ occurred in the whole peat. The most influential parameter for CEC was a content of organic matter (expressed by ash content).

The highest values of CEC were noted in a carbonate peat with the highest $\mathrm{pH}$ (type 1), regardless of ash content and type of peat. The research proved that carbonate peatlands can be the most effective geological barrier due to their CEC values. Next to the content of the organic matter, the content of $\mathrm{CaCO}_{3}$ influenced the $\mathrm{pH}$ and was a decisive factor for the $\mathrm{CEC}$ value.

\section{Acknowledgements}

The authors are indebted to Dr Daniel Okupny from the Institute Geography of the Pedagogical University in Cracow and an anonymous reviewer for helpful comments and recommendations.

\section{REFERENCES}

Andrejko, M. J., Fiene, F., Cohen, A. D., 1983. Comparison of Ashing Techniques for Determination of the Inorganic Content of Peats. In Jarret, P.M. (Ed.) Testing of peats and organic soils, 5-20. American Society for Testing and Materials, Philadelphia.

Appelo, C. A. J., Postma, D., 1993. Geochemistry, groundwater and pollution. CRC Press.

Allen, S.J., Mckay, G., Porter, J.F., 2004. Adsorption isotherm models for basic dye adsorption by peat in single and binary component systems. Journal of Colloid and Interface Science 
280, 322-333.

Beckwith, C.W., Baird, A.J., Heathwaite, A.L., 2003a. Anisotropy and depth-related heterogeneity of hydraulic conductivity in a bog peat. I, laboratory measurements. Hydrological processes $17,89-101$.

Beckwith, C.W., Baird, A.J., Heathwaite, A.L., 2003b. Anisotropy and depth-related heterogeneity of hydraulic conductivity in a bog peat. II, modelling the effects on groundwater flow. Hydrological Processes 17, 103-113.

Boelter, D.H., 1965. Hydraulic conductivity of peats. Soil Science 100, 227-231.

Borkowski, A., Rydelek, P., Szala, M., 2013. Adsorption studies of azotetrazolate and 3,6-dihydrazinotetrazine on peat. Journal of Environmental Science and Health A 48, 905-911.

Borówka, R. K., Tomkowiak, J., Okupny, D., Forysiak, J., 2015. Chemical composition of biogenic sediments from the river valley Luciąża (Bęczkowice peatland in the Piotrków Plain). Folia Quaternaria 83, 5-23 (in Polish with English summary).

Borys, M., 1993. Niskie nasypy z miejscowych gruntów organicznych dla potrzeb budownictwa wodno-melioracyjnego. Wydawnictwo IMUZ, Falenty (in Polish).

Domińczak, P., Okupny, D., 2010. Spatial variability of selected physicochemical properties of biogenic sediments in the Kopanicha peatland near Skierniewice. Prace Geograficzne 123, 99-110 (in Polish with English summary).

Dorn M., Tantiwanit W., 2001. New methods for searching for waste disposal sites in the Chiang Mai-Lamphun basin, northern Thailand. Environmental Geology 40, 507-517.

Falkowska, E., 2002. Geomorphological conditions of the occurence of the natural isolation barriers in selected river valleys of the Polish Lowlands. Przegląd Geologiczny 50, 929-936 (in Polish with English summary).

Falkowska, E., 2009. Glacial morphogenesis of uplands of the Warta Glaciation in Poland as a control on heavy metal distribution in deposits. Geological Quarterly 53, 293-304.

Ho, Y.S., McKay, G., 1999. The sorption of lead II ions on peat. Water Research 33, 578-584.

Hoag, R.S., Price, J.S., 1995. A field-scale, natural gradient solute transport experiment in peat at a Newfoundland blanket bog. Journal of Hydrology 172, 171-184.

Hobbs, N.B., 1986. Mire morphology and the properties and behaviour of some British and foreign peats. Quarterly Journal of Engineering Geology and Hydrogeology 19, 7-80.

Ingram, H.A.P., 1978. Soil layers in mires, function and terminology. Journal of Soil Science 29, 224-227.

Kittel, P., Płóciennik, M., Borówka, R. K., Okupny, D., Pawłowski, D., Peyron, O., Stachowicz-Rybka, R., Obremska, M., Cywa, K., 2016. Early Holocene hydrology and environments of the Ner River (Poland). Quaternary Research 85, 187-203.

Kyzioł, J., 2002. Effect of physical properties and cation exchange capacity on sorption of heavy metals onto peats. Polish Journal of Environmental Studies 11, 713-718.

Langer, M., 1998. Engineering geological evaluation of geological barrier rocks at landfills and repositories. Environmental Geology $35,19-27$.

Łuczak-Wilamowska, B., 2013. Geological conditions of municipal waste landfilling. Biuletyn Państwowego Instytutu Geologicznego 455, 1-142 (in Polish with English summary).

Ma, W., Tobin, J.M., 2004. Determination and modelling of effects of $\mathrm{pH}$ on peat biosorption of chromium, copper and cadmium. Biochemical Engineering Journal 18, 33-40.

Majer, E., 2007. Methodology of assesment of soil for designig of compacted clay liners (CCLs) in landfills. Geologos 11, 239252 (in Polish with English summary).

Myślińska, E., 2010. Laboratoryjne badania gruntów i gleb. Wydawnictwa Uniwersytetu Warszawskiego (in Polish).
Okruszko, H., 1974. Zasady podziału gleb organicznych. Wiadomości Instytutu Melioracji i Użytków Zielonych 12, 19-38 (in Polish).

Okruszko, H., 1976. Zasady rozpoznawania i podziału gleb hydrogenicznych z punktu widzenia potrzeb melioracji. Biblioteczka Wiadomości Instytutu Melioracji i Użytków Zielonych 52, 7-54 (in Polish)

Okruszko, H., 1994. System of hydrogenic soil classification used in Poland. Biblioteczka Wiadomości Instytutu Melioracji i Użytków Zielonych 84, 5-27.

Pawłowski, D., Okupny, D., Włodarski, W., Zieliński, T., 2014. Spatial variability of selected physicochemical parameters within peat deposits in small valley mire: a geostatistical approach. Geologos 20, 269-288.

Pawłowski, D., Borówka, R.K., Kowalewski, G.A., Luoto, T.P., Milecka, K., Nevalainen, L., Okupny, D., Tomkowiak, J., Zieliński, T., 2016. Late Weichselian and Holocene record of the paleoenvironmental changes in a small river valley in Central Poland. Quaternary Science Reviews 135, 24-40

Rizzuti, A.M., Cohen, A.D., Stack, E.M., 2004. Using hydraulic conductivity and micropetrography to assess water flow through peat-containing wetlands. International Journal of Coal Geology $60,1-16$.

Rydelek, P., 2005. Genetic conditions of spatial variability of Total Organic Carbon (TOC) and sulphur concentration in the peat bog area of Kurówka River Valley. Przegląd Geologiczny 53, 673-676 (in Polish with English summary).

Rydelek, P., 2011. Peatlands of Lubartów Upland as the potential natural geological barriers. Biuletyn Państwowego Instytutu Geologicznego 446, 407-416 (in Polish with English summary).

Rydelek, P., 2013. Origin and Composition of Mineral Constituents of Fen Peats from Eastern Poland. Journal of Plant Nutrition 36, 911-928.

Rydelek, P., Bąkowska A., Zawrzykraj P., 2015. Variability of horizontal hydraulic conductivity of fen peats from eastern Poland in relation to peatlands as natural geological barriers. Geological Quarterly 59, 426-432.

Sapek, B., 1982. Pomiar sorpcji miedzi jako test oceny pojemności sorpcyjnej utworów organicznych. Roczniki Gleboznawcze 38, 343-349 (in Polish)

Syrovetnik, K., Malmström, M.E., Neretnieks, I., 2007. Accumulation of heavy metals in the Oostriku peat bog, Estonia, determination of binding processes by means of sequential leaching. Environmental Pollution 147, 291-300.

Ścibior, K., Rydelek, P., Stępień, M., 2015. Influence of selected peat bogs Drawa National Park on the formation of the chemical composition of shallow groundwater. Przegląd Geologiczny 63, 1099-1104 (in Polish with English summary).

Twardowska, I., Kyziol, J., 1996. Binding and chemical fractionation of heavy metals in typical peat matter. Fresenius' journal of analytical chemistry $354,580-586$.

Twardowska, I., Kyziol, J., Goldrath, T., Avnimelech, Y., 1999. Adsorption of zinc onto peat from peatlands of Poland and Israel. Journal of Geochemical Exploration 66, 387-405.

Zhou, W., Li, G., 2001. Geological barrier - a natural rock stratum for preventing confined karst water from flowing into mines in North China. Environmental Geology 40, 1003-1009. 